Nancy J. BARRIOS AULAR

Catholic University of Táchira

Nathalia K. RIVAS PÉREZ

Catholic University of Táchira

\title{
COLOMBIAN-VENEZUELAN BORDER INTEGRATION: THE UTOPIA OF THE TÁCHIRA STATE AND THE DEPARTMENT OF NORTE DE SANTANDER
}

ABSTRACT The paper discusses the integration process of the Colombian-Venezuelan frontier in 2005, which included the regions of Táchira and Norte de Santander, as an experience initially made in the legal framework of the Andean Community of Nations (Spanish: Comunidad Andina de Naciones, CAN). Decision 501 facilitates the creation of a border integration zone - BIZ - that would contribute to and strengthen the border development, in an area that has juridical, administrative and functional conducive conditions. For this reason, a Border Integration Zone - BIZ - would help counteract backwardness and make possible a number of joint regional projects that would give support to integration.

The study shows a retrospective analysis of binational discussion topics as far as it was possible within the dialogue, and before the obstacles that stopped the way which concluded with the cancellation of the negotiation rounds in 2008. At the same time, it considers the Venezuelan role afterward Colombia had signed the free trade agreement with the US, and the perception of this fact by the border inhabitants of Táchira state. In a reality that the development perspectives, based in markets integration, are not clear inside the Venezuelan geopolitics to become part of the process.

KEY WORDS Integration, development, frontiers, society, policies. 
$\mathrm{T}$ o describe the process of boundary integration between neighboring countries like Venezuela and Colombia, it would entail the question of where does a border start or end? Border Integration includes sociological and economical concepts inherent to the bonds between the people who daily coexist in the geographic scenarios. They have to deal with different legal systems that respond to geopolitical lines of each State (vertical order) and they also have to handle interdependent relationships with different situations in which geographic, social, educative, cultural, and security factors, promoted by societies, in one or other place (vertical order), vanish. Besides, the State assets and establishes its own international relations policies in the geopolitical interaction of societies.

This fact shows the perceptive analysis of the borders practical reality, especially between Táchira and the Department of Norte de Santander. It seems connected with the economic opening up and globalization between countries. It also unites the role of the regions as representative agents of neighbor relationships and subordinates to the balance of the nations' interests, with lacks of legal and economic complementarity that regulate the development projects that nations aspire to as development promoters. Nevertheless, to establish in those regions a diplomatic, strategic integration processes combining the creation of transactions with all the limits, then negotiations to strengthen the exchange and operations between institutions will not be one hundred per cent feasible.

At present, the processes of border integration with a global tendency implies to see the border as action shared areas that need policies to boost the development. Oliveros (2002) understands the processes as: Processes agreed by two States in their border territories through agreements or treaties. Their main objective is to favor development in the union basis and complimentary use of their potentialities, resources, and similarities, as much as costs and shared benefits that are a central component of progress and reinforcement of the bilateral relationship. ${ }^{1}$ It is necessary to specify how will be the reciprocal relationships when societies share actions with common and different elements, in order to manage the interdependent relations because there are many power issues.

Certainly, there are some national and border characteristics that look for the identification of principles in which to think before establishing strategies to favor integration processes. If political borders do not always coincide with economic borders, the other face is that politics and economics are inseparable elements, even more when there are contexts with two points of view. Firstly, a tridimensional idea that includes the border region itself, its relation with the rest of its own country, and its influences with the nearby land that matches the sovereignty criteria, border management and routine aspects. Secondly, economic variables as dynamic motor of the binational relationships and, at the same time, conflictive for the concurrence of internal and foreign agents related with resources, markets, and localization advantages that remain even when there are political obstacles with no diplomatic transcendence. The interception

L.A. Oliveros, El concepto de frontera en el contexto y en la perspectiva de la integración andina, 2002. 
of political and economic borders produced by States-Nations from society demands that require definition of programs and complementary projects, socioeconomics and environmental, without detriment of the parties.

Venezuela evaluated the conditions of the international relationships and the political, judicial, and administrative parameters of both countries before setting a geopolitical strategy of society interaction and undertaking initiatives for border integration process. Thus, the historic character and the economic dynamism of the trade relationships in the border regions of Táchira state and the Department of Norte de Santander became more public, formal, and precise in 2005, making the parties consider diplomatic initiatives of integration, cooperation, and exchange in the chancellery level of both countries using the form of Border Integration Zones (BIZ). The BIZ rises in the legal framework of Andean Community of Nations (CAN) Decision 501, in order to consolidate and to develop the border zone, under juridical, administrative and functional conducive conditions to reverting situations of backwardness, making likely to reach joint regional projects that were giving support to the integration.

Subsequently, when Venezuela announced its withdrawal from CAN in 2006, the integrationist process showed obstacles in the international relations and, as a consequence, it started to disappear, in time and space, the gestation of the desired integration of border regions as initially planned and changed the formulation process of common interest projects in specific areas. This fact maximized the border perception of being spaces that are isolated and few connected to interact and to assist local and global development mechanisms.

This point of view is a departure point for an analysis of what it was about the Colombian-Venezuelan border integration that combined different meetings on diplomatic and political levels, and the presence of the regions through the meetings of the Governors of Táchira state and the Department of Norte de Santander. The integration opening meeting held in 2001 made possible the special Declaration of the Presidents of Colombia and Venezuela with a marked interest in reinforcing bilateral relation-ships. The statement establishes the creation of a common fund to belp the strengthening of social investment in the border that permits to raise the standard of living and sets a proper atmosphere for mutual and active community participation in the binational integration processes. ${ }^{2}$

The regions started a study entitled: "Proposal of definition and delimitation of the Border Integration Zone Táchira-Norte de Santander" 3 and finished it in 2005. The study allowed selecting the places that would make up the BIZ. The places in Táchira are Ayacucho, Bolívar, Cárdenas, Córdoba, Fernández Feo, García de Hevia, Independencia, Junín, Libertad, Libertador, Lobatera, Pedro María Ureña, Rafael

\footnotetext{
Declaración Especial de los Presidentes de Colombia y Venezuela sobre la Creación de un Fondo Común para el Fortalecimiento de la Inversión Social en la zona de Frontera, 4 de mayo de 2001, Bogotá, p. 2.

3 Universidad de Los Andes. Centro de Estudios de Fronteras e Integración - CEFI Venezuela. Corporación Universidad Libre de Colombia. Universidad Francisco de Paula Santander, Propuestas Definición y Delimitación de la Zona de Integración Fronteriza área Norte de Santander (Colombia) Táchira (Venezuela), 2005.
} 
Urdaneta, San Cristóbal and Torbes. The places in Norte de Santander are: Cúcuta, Chinacota, El Zulia, Los Patios, Pamplona, Pamplonita, Puerto Santander, Ragonvalia, San Cayetano, Toledo, Villa del Rosario.

Furthermore, the First Binational Meeting Agreement to propose the creation of the Border Integration Zone Táchira state (Venezuela) and the Department of Norte de Santander (Colombia) took place in San José de Cúcuta, on July 6th, 2005. In this meeting, the Colombian representative of the Presidential Commission for Border Affairs (Spanish: COPIAF) and the General Director of Sovereignty, Boundary and Border Affairs of Venezuela made emphasis on the progressive and flexible character of the geographic defining the space for monitoring and evaluation; in order to guarantee the objectives of BIZ, established by Decision 501, and to describe related topics to use in binational dialogue groups. Along these lines, in July 2006, the "First Binational Meeting of the Working Group for the creation of the Border Integration Zone Táchira - Norte de Santander" took place, in which Governors agreed that BIZ must be created as soon as possible.

The Declaration of Punto Fijo ${ }^{4}$ was remarkable for border integration. It was on November 24th, 2005, by the Presidents of Venezuela, Hugo Chávez Frías and Colombia, Álvaro Uribe Vélez, to instruct the Foreign Ministries and the Governments about the Integration Zone (BIZ). This made possible a proposal for integration, one to strengthen politics, as well as the administrative and juridical grounds of the exchange relations that proximity gives. This gave rise to more interest in the meetings. The Binational Governors and Specialists Meetings allowed the participants to discuss the common problems and regulations of the region. Chancelleries proposed nine topics 5 , such as:

Culture: exchange of experiences and artistic and cultural meetings.

Tourism: Training and tourist programs exchange. To create a Bolivarian Card and to show more flexible forms of address of the authorities in the border.

Public Health: it was a concern the analysis of the legal systems of both countries to offer a significant public health service. In Colombia, the Law 715, 2001 and in Venezuela, the Constitution that set up free Public Health programs.

Education: exchange of educational experiences and educational programs; focus on sexual reproduction prevention, gender equity, and drugs use and abuse.

Finances: a proposal for funds transportation from Norte de Santander to Venezuela, for protection and currency exchange.

Infrastructure: regulation of border transportation and the Project for the binational metropolitan border which included the study of the enlargement of the international "Simón Bolívar" and "Francisco de Paula Santander".

Coal and Phosphates: To evaluate the technical and financial possibilities of the recovery and restoration of a carbo-chemical industry in the Capacho area of

Ministerio de Relaciones Exteriores de la República Bolivariana de Venezuela, Declaración de Punto Fijo, 2005, p. 1.

5 N. Barrios Aular, 'Propuestas de las mesas técnicas reuniones binacionales de gobernadores 2007, Revista Zona de Integración Fronteriza. Integración y Cooperación, Táchira 2008, pp. 42-43. 
Táchira, specifically in the area known as Hato La Virgen, understood as a revival of the BIZ industrial development, enabling the transformation of the coals on both sides of the border in the products that the industry could develop.

Water: designing of the Project "Master Plan for drinking and cleaning Water Service to Villa del Rosario- Colombia and Bolivar Ureña- Venezuela".

Sugar Cane: to create a regulatory system for handling and transportation. To determine which regions of both countries will be part of the integration territory for transportation and production.

At the same time, the integration process proposed for the social economic scope, reached the designing of academic studies, which led to proposals for the following projects:

- To promote cluster development for a leather factory in Pedro María Ureña, Bolívar and Norte de Santander. ${ }^{6}$

- To create a specific system to rule vehicle assemblers.

- To coordinate basic mechanisms for labor integration in the BIZ: work market and factors that affect its strength.

We might well include the security and energy agreement that are necessary to improve the transport of Venezuelan gas to the Department of Norte de Santander, as an option to reduce the gas smuggling in the Colombian-Venezuelan border region. This resulted in the crossing of 11 Venezuelan gas trucks transporting gas to the Department of Norte de Santander on August 21th, 2008.

The Binational Committee made possible eight Governors meetings ${ }^{7}$ between 2006 and 2007, with the presence of diplomatic authorities. The meetings took place on the following dates: first meeting held in Cúcuta on January 26th, 2006 to identify potentials and projects of common interest for the BIZ. Second meeting held in San Cristóbal, Táchira on March 3rd, 2006: this meeting promoted support of diplomatic notes to be exchanged between the foreign ministries of Colombia and Venezuela. Third meeting held in Norte del Santander on December 12th, 2006, conferred preeminence to start the Sugar Cane topic in the BIZ. Fourth meeting held in Cúcuta on March 3rd, 2007 to monitor the progress of the topics previously worked in discussion groups. Fifth meeting in San Cristóbal on April 12th, 2007, requested the participation of the Presidential Commissions for Border Affairs of both countries to assess the monitoring of the topics. Sixth meeting held in Pedro María Ureña Municipality on October 3rd, 2008 to assess the progress son the Sugar Cane topic. This meeting produced an agreement to submit to the Chancelleries for the development of sugar cane cultivation. Seventh meeting took place in Villa del Rosario on October 24th, 2008 to assess the progress of binational specialists' dialogue groups. Eight meeting was held in San Cristóbal on November 18th, 2008 to maintain the creation process of the BIZ.

6 J. Bustamante Urbina, El Desarrollo de Cluster de manufacturas del cuero para los Municipios Pedro Maria Ureña, Bolivar y el Norte de Santander, Táchira 2008.

N. Barrios Aular, 'Propuestas..., pp. 28-29. 
Those meetings had already proved the diplomatic failure of the relations between the countries, especially obvious on the fifth and sixth binational meeting, for many reasons: Colombia placed toll booths at two border crossings in El Escobal and La Parada, a few meters away from Simón Bolivar International Bridge. This situation shut the border down on July, 2007 because a toll booth means the breaking of a tradition of service older than one hundred years, economically affecting the border crossing especially for heavy-load carriers and public and private transport.

Almost immediately, in December 2007, due to the mediation of President Hugo Chávez, and the meetings of high officials of Colombia and Venezuela to accomplish the release of hostages by the FARC and ELN (Clara Rojas' case and her son Emmanuel along with other persons), an incident arises that provoked the freeze of the relations between the two countries, because Colombia considered that the Venezuelan president's calls to Colombian military commanders were equal to giving them instructions, and asking for information of the military efforts in this case were an interference in the internal affairs of Colombia. This obviously distanced regional integration with mutual distrust between these two countries, which was already evident at the beginning of the efforts for integration.

Hence ended the year 2007 and part of more than half of 2008, without further integrationist developments at the regional level, understanding once again, that borders are spaces for dialogue, where politicians have the last word.

Thus in 2008, in the month of March, within the already distanced the Venezuelan - Colombian relations another issue arose, in Ecuador the FARC guerrilla's boss Raul Reyes died, in the hands of the Colombian military, on Ecuadorian territory, which was considered as a serious matter of violation of the sovereignty of Ecuador, a fact which was denied by the Colombian president. However, Venezuela adopted a position of solidarity with Ecuador, closing its embassy in Bogotá, while sending ten battalions to the border with Colombia and deploying military air forces, accompanied by verbal threats such as closing of trade with Colombia, which amounted to about 5,000 million dollars, and substituting it with trade with Brazil and Argentina. This continued until later in 2008. It is worth to bear in mind, though, that in Venezuela this was the elections period for new governors in the regions.

In January 2009, a new Government in Táchira state, elected democratically and ideologically independent of national policy, organized a meeting on March 26. In this meeting, the Governors of Táchira and Norte de Santander analyzed key aspects of road integration as a possible solution for the traffic jams in the border zone, in Bolivar (Venezuela) and Villa del Rosario (Colombia), which went from the area of Peracal to Llano Jorge route connecting to Colombia next to Corregimiento Juan Frío in Villa del Rosario. Venezuelan Foreign Ministry did not support the proposal, and as a consequence, the integration process started to decrease.

In addition, Venezuela broke off diplomatic relations with Colombia on July, 2009. The reason was the acceptance, supported in each state, of localizing seven United States military bases on Colombian territory. This caused the suspension of gas supply to the Department of Norte de Santander. Later, on November 2nd, 2009 the border crossing 
in the Simon Bolivar and Francisco de Paula International bridges was closed (pedestrian and traffic) for the killing of two Venezuelan officers of the National Guard.

The sour diplomatic relations have negatively affected the economy ties between the two countries, which has created a recession that impacts all levels, including goods transportation. Colombia's Government considers the breaking a "trade embargo". Venezuelans could not pass the border as regularly. The conflict arose the Río Meeting held in Cancun, in February, 2010. Later, on April 14th of the same year, President Uribe issued a travel warning. Then, on April 19th, 2010 Colombia accused Venezuela of violating the Vienna Convention.

The crucial moment of the conflict was on July 22nd, 2010 when Venezuela announced the breaking off of diplomatic relations with Colombia again. It came after President Uribe requested the Organization of American States (OAS) to establish, for thirty days, an International Commission to verify the existence of guerilla camps (FARC and ELN) in Venezuelan territory. Afterwards, there took place the meeting of the Union of South American Nations (Spanish: UNASUR) in Quito on July 29th, 2010 to alleviate conflict between Venezuela and Colombia and adopt mechanisms that would permit the reinforcement of dialogue and peace - but Colombian Government maintained the conflict and rejected the dialogue for peace.

After the investiture of Colombia's new President, Juan Manuel Santos on August 7th, 2010, there began a new method of negotiations for the reestablishment of the relations between the two countries. A new meeting between the Foreign Ministries of Colombia, Mariangela Holguin and Venezuela, Nicolás Maduro, took place on August 10th, 2010. During this meeting, the Ministers approved the creation of five commissions that would help to reestablish Colombian-Venezuelan relations, especially in trade. The commissions included the following topics:

1. Payment of remaining debts with Colombian exporters.

2. Reactivation of trade relations.

3. The study of economic complementation agreement for the social investment in the border.

4. The construction of Binational Infrastructures.

5. The implementation of a common Border Security.

Certainly, the main purpose of the commissions turned into the progress for the reestablishment of the border dynamism, such as the border in Táchira and Norte de Santander, which is of huge importance in South America. The conflict showed that the handling of the integrationist issue is necessary regionally and nationally with a variety of interests. Colombia knows extremely well what it does need from Venezuela to position its products, but it does not see it as an exclusive client. During the conflict, it looked for other markets or business allies and investments that added more profitability (employment rate raising and a better standard of living, supporting exports of small and medium businesses). Besides, it signed the Free Trade Agreement with the United States (CTPA) on May 15th, 2012. Colombia also recognizes Venezuelan market's instability, but it has an interest in its projects, especially energy projects. In other words, Colombia is a member of an agreement of 49 countries 
that promotes national and foreign investment since permits soft loans, with juridical and political support.

Venezuela, for its part, assumes a socialist economic model for the market economies that do not see economy competitively. Its exclusive dependence of oil revenues (fifth oil exporter in the world) causes closure of businesses and few guarantees to productive apparatus of reactivation in the border regions, currency exchange control, and all decisions must be taken at a central level. This is, Venezuela's economy is becoming more import dependent every day. As a consequence, there is a tremendous flight of capital (American dollars) and weakening of domestic production. Regarding The United States-Colombia Trade Promotion Agreement (CTPA), Venezuela might be affected for the "take-back effect" because Colombia will buy more products from the United States and, this will affect neighboring markets causing more smuggling and redeployment of businesses, capital, and workforce to Colombia for its potential as a great market to export to.

In this context, Colombian-Venezuelan Border Integration represents the utopia of Táchira state and The Department of Norte de Santander. The retrospective analysis shows that time and diplomatic frictions influence the inclusion of regional integration in Government's agenda. This approach reinforces inside the introspection of the topics that the Commissions created in 2010 and the subscription of agreements between Colombia and Venezuela on November 2nd of the same year regarding economy, energy, security, tourism, and culture. The Presidents agreed the reestablishment of oil supply to border regions in Colombia and chose November 19th to discuss drug trafficking fight.

Looking from a regional and geopolitical point of view, these circumstances create a point of exclusion or not admission in the agendas to favor integration and, consequently, a progressive degradation of the strategic position regarding the connections that must exist between national, regional and local. We will see whether Venezuela is a country open to trade, cooperation and respectful relations with its neighboring countries, a republic that fights poverty that promotes trade interests in balance with the human rights, a nation that gives special and different form of address for unequal economies to offer opportunities for the weakest as a public policy. Internally, Táchira-Norte de Santander inhabitants think the conflict has created a blanket of obscurity to cover and hide the reality of the border region. The only measure undertaken by both governments has been a militarization of the zone that has not managed to prevent the gradual strengthening of the problems. Some problems that are considered outside the Committee are:

- Impact and backwardness of the Border Integration Zone after the diplomatic conflict in 2008.

- Identification of bi-national interest projects that can be developed with international cooperation.

- Traffic jams caused by gas smuggling.

- Discussion of binational border passing.

- Táchira as recipient of the immigrant population which causes social problems. 
- Double nationality in which Colombia does not show interest.

- Food safety. There is food shortage and illegal food smuggling in considerable amounts.

- Outrage and bad behavior of officials with the persons when passing the border.

- Inside the country: a lack of regulations to rule the border relations. There is not a Border Law, established by the Constitution on Article 15. In addition, there are uncertainty economic conditions after Venezuela announced its withdrawal of CAN in 2006, because goods would cost between five and twenty percent of taxes.

All these elements have caused mutual distrust in Táchira and Norte de Santander border. Consequently, this distrust implies social security, juridical, and political aspects connected with the emotions in the diplomacy which the dynamism of the border. It seems that no interest has characterized the recent Venezuela-Colombia relationship. The Presidents of Colombia and Venezuela signed eleven agreements to strengthen the binational trade on November 29th, 2011. The agreements include the following topics: ${ }^{8}$

Trade: Tax preferences in three thousand and five hundred products for both countries.

Energy and Petroleum: Creation of a mixed company for the construction of an oil pipeline to connect The Orinoco Belt with Puerto Tumaco on the Pacific Coast. Extension of the gas pipeline that connects Campo Ballena in the Colombian Guajira with the Maracaibo Lake towards Panama and Ecuador.

Electricity: Agreement for the Exchange of Energy between San Fernando de Atabapo - Venezuela and Puerto Inírida - Colombia through National Electricity Corporation (Spanish: CORPOLEC) Venezuela and the Institute of Planning and Promotion of Electrical Solutions (Spanish: IPDE) Colombia.

Science and Technology: Agreement between Intermmediate Industries Corporation of Venezuela (Spanish: CORPIVENSA) and Colombian Company FORSA to create an aluminum and steel production facility to manufacture industrial scaffolding.

Culture: To make progress in cooperation and cultural, academic, and research exchange.

Public Health: Agreement between Venezuelan Ministry of Health and Colombian Companies Vitrofarma S.A. and Vitalis SACI to create a mixed corporation to build a generic medicine factory in Carabobo, Venezuela.

Food and Agriculture: Venezuela will buy twenty thousand dairy cows and calves and steers to Colombia.

Despite this perceptible and undeniable reality, we have the obligation to express, think, and propose possible alternatives to help the improvement regional development. The way is to demand solutions to solve the problems that the border suffers.

'Venezuela y Colombia suscriben once acuerdos', El Mundo at <http://www.elmundo.com/portal/ noticias/economia/colombiayvenezuelasuscribierononceacuerdos.php>, 29 November 2011. 
Venezuela cooperates with the United Nations in five topics: public health and human rights, poverty reduction, food safety, social and gender equity programs, education programs, values and equity, human development, participation and social production, environment protection, risk management, and humanitarian help.

Nowadays, we can start our way to solving many problems that affect the inhabitants of the border. By designing and planning feasibility projects, we can be eligible for international cooperation. Meanwhile, time will create the conditions to achieve the desired border integration.

However, one must keep in mind the processes of change taking place in the world. Colombia and Venezuela already have experience with the consequences which have resulted in times of stress, they know their weaknesses their levels of distrust are camouflaged, but the rough edges persist even when diplomacy is used.

Although, to Venezuela, the national Constitution, in its Article 15, refers to the establishment of (...) a comprehensive policy on land border areas, islands and sea, preserving territorial integrity, sovereignty, security, defense, national identity, diversity and environment, according to the cultural, economic, social and integration development (...). One has to wonder, to what extent there is an opening regarding integration, as there are legal and institutional loopholes (relations of coexistence and neighborhood), which are linked to economic and political obstacles that will detonate if left unchecked and unchallenged.

This fact makes us reflect on it, through the formulation of some questions related to the way development is promoted: what role do the inhabitants of the border regions play within the changes, currently displayed on the map with a macro - global integration, which seems to ignore the glocal position? What are the new challenges faced, considering the mutual distrust and the need to strengthen the relations of coexistence? If political and economic concepts are intermingled with those of sovereignty and territoriality, affecting relations between the two countries, at what time would the cross-border integration be taken up - at the expense of the existing delimitation negotiations on the Gulf of Venezuela (to Venezuela) or the Gulf of Coquibacoa (to Colombia). Indeed, to think about integration, each country should set challenges for itself that would go beyond the threats that distance them from each other - to make possible the dialogues regarding the issues involved, so that may not be a mere paraphrase of utopias anymore.

\section{REFERENCES}

Barrios Aular N., 'Propuestas de las mesas técnicas reuniones binacionales de gobernadores 2007', Revista Zona de Integración Fronteriza. Integración y Cooperación, Táchira 2008.

Bustamante A., F. Sánchez, Régimen Especial para el Sector de ensambladoras de vehiculos para el transporte de pasajeros, Táchira 2008.

Bustamante Urbina J., El Desarrollo de Cluster de manufacturas del cuero para los Municipios Pedro María Ureña, Bolivar y el Norte de Santander, Táchira 2008. 
Caraballo L., Mecanismos Imprescindibles para la integración laboral en la ZIF. Mercado de trabajo y los Factores que generan su fortalecimiento, Táchira 2008.

Declaración Especial de los Presidentes de Colombia y Venezuela sobre la Creación de un Fondo Común para el Fortalecimiento de la Inversión Social en la zona de Frontera, 4 de mayo de 2001, Bogotá.

Ministerio de Relaciones Exteriores de la República Bolivariana de Venezuela, Declaración de Punto Fijo, 2005.

Oliveros L.A., El concepto de frontera en el contexto y en la perspectiva de la integración andina, 2002.

Universidad de Los Andes. Centro de Estudios de Fronteras e Integración - CEFI Venezuela. Corporación Universidad Libre de Colombia. Universidad Francisco de Paula Santander, Propuestas Definición y Delimitación de la Zona de Integración Fronteriza área Norte de Santander (Colombia) Táchira (Venezuela), 2005.

'Venezuela y Colombia suscriben once acuerdos', El Mundo at <http://www.elmundo.com/por$\mathrm{tal} /$ noticias/economia/colombiayvenezuelasuscribierononceacuerdos.php $>, 29$ November 2011.

Nancy J. BARRIOS AULAR, Political Scientist, Universidad de Los Andes - Mérida (1993). Professor at Universidad Católica del Táchira, Law Faculty (School of Political Science). She has worked in the Border Commission and the International Relations Commission for the regional government of Táchira. She was a member of the group to prepare the document: "Project: Proposal of conception and creation of the Border Integration Zone: Norte de Santander (Colombia) - Táchira (Venezuela)” April, 2005 .

Nathalia K. RIVAS PÉREZ, Attorney, Universidad Católica del Táchira. Magister in International Law and International Relations, Universidad Complutense de Madrid - Spain. Instructor Professor at Universidad Católica del Táchira, Law Faculty. She is a member of the Forum of International Legal Studies and Global Development (Spanish: FEJID). Director of International Relations and Liaison of Táchira State Government (2009-2013). 